\title{
Management Analysis of Karate Sports Coaching at Kei Shin University Kan Karate-do North Sumatera
}

\author{
Rafika Ardilla \\ Department Of Sport Education \\ Post Graduate Program, State University Of Medan \\ Medan, North Sumatera, Indonesia. \\ rafika.ardilla@gmail.com
}

\begin{abstract}
This research will be conducted at Kei Shin Kan Karate-Do College of North Sumatera because it is a major college of Karate in North Sumatra. The approach taken in this study is a qualitative approach means the problems discussed aims, to be able to describe or describe the existing state or phenomenon or research process to understand human or social problems, based on a complex order, a holistic picture, said, reporting the informants' detailed views and carried out in a natural setting. In this study, the respondents or subjects were: 1) official, 2) trainers, 3) athletes and 4). community or athlete's parents. Data collection techniques can be done by 1) observation 2) interview 3) documentation 4) combined / triangulation.
\end{abstract}

Keywords - Sport Management; Coaching; Karate.

\section{INTRODUCTION}

The development of karate sports in Indonesia, is currently so rapidly aimed at with many branches of karate college that stand in all regions both in big cities to districts. The purpose of establishing these karate branches is to conduct training so that the karateka can perform optimally. The success of coaching the karate sport is determined by the quality of coaching carried out by the branch concerned.

North Sumatra is one of the provinces where the development of karateka can be said to be comprehensive to the existing cities and districts. Coaching is not only by opening a dojo but by opening extracurricular activities at schools. Karate universities in North Sumatra are well developed, one of them is Kei Shin Kan Karate-Do North Sumatra. Kei Shin Kan Karate-Do has many pengcab namely Medan, Deli Serdang, Binjai, Tanah Karo, Central Tapanuli, Simalungun, Toba Samosir, and South Nias. Kei Shin Kan Karate-Do North Sumatra has 64 dojo, 1532 kohai, and 123 coaches. Kei Shin Kan Indonesia Karate-Do was founded in 1972 by John Angkawijaya and its management was formed in 1975. Then with Sinsei Yoeshar Hasan developed in North Sumatra
Kei Shin Athlete North Sumatra Kan Karate-Do has decreased in participating in the national championship representing North Sumatra FORKI every year. Meanwhile, if analyzed that the total number of Kei Shin athletes in North Sumatra Karate-Do Kan is very far from the number of participating athletes. Based on the results of an interview with Mr. Putra Kelana (North Sumatra Forki referee board), according to his observation that most athletes during the match feel anxious (mental decline), especially when dealing with athletes who already have names, have ranked in Kejurnas, PON, and Sea Games . This is because experiencing pressure before and during a match, such as some athletes who complained that they could not sleep before the game, were restless, uneasy and during the match athletes complained of feeling abdominal pain, body fit, decreased self-confidence, and many other things that greatly affected match results.

Training of sports achievements is a systematic and sustainable long-term process. In this long process, wellcoordinated support resources and high commitment from various parties are needed. The development of sports achievement which is the goal of sports achievement is one of the programs needed in sports development. Achievement sports coaching aims to foster achievement or actualize the potential of talent into the appearance of sportiness with standard forms, qualifications, and rules. Without ignoring the basic principles of other coaching, presumably in some aspects the principles of learning need to be considered in developing a sports coaching program.

Coaching and development of achievements include athletes, workforce / trainers, organizing, funding, methods, training programs, facilities and infrastructure as well as sports awards that are carried out through the sport recognition stage. Training of sports achievements is carried out and directed to achieve sports achievements at the regional, national and international levels carried out by parent organizations at the central and regional levels. According to Ruslin Lutan (2000: 45) that in the process of coaching in 
each sport there are at least nine key elements that are interrelated with one another: 1) the purpose of coaching (priority), 2) athletes, 3) trainers, 4) programs coaching, 5) sports infrastructure and facilities, 6) learning resources, 7) methodology, 8) education and evaluation and, 9) costs. The purpose of coaching each sport has the purpose of fostering each, both at the regional, national and international levels, in relation to the objectives to be achieved so there are certain policies and priorities. Athletes are objects and at the same time subject in coaching. The success of the coaching process in achieving goals, depends a lot on the potential of the athlete and the ability of coaching to generate this potential. Therefore. a) the process of guiding talent, b) determining the right branch or number for a prospective athlete, c) coaching based on a strong and integrated national ideology with a pedagogical approach, and d) future career guidance is an important factor to be considered, in order to achieve coaching Coaching programs are a series of selected activities and priorities. Its nature is dynamic and always oriented to the needs of an athlete. There will be similarities in aspects that are fostered through a comprehensive program, namely: a) Guiding attitudes that are ready to receive and work on dominant coaching training in order to increase knowledge back to the ability to assess the situation at hand. b) Coaching other effective traits, such as emotional stability, resilience in overcoming stress, willingness led by others, discipline or loyalty to existing norms and others. c) Increased motor efficiency, ranging from basic techniques to complex movements that increase mastery of techniques, both longterm nature prepared in advance and situational tactics, d) Improved physical conditions. Sports facilities and infrastructure are sports facilities which are important elements. To carry out coaching activities both in the community by the community such as in recreational sports activities, there is still a strong tendency that facilities that meet needs are still far from adequate.

Basically to become an achievement sports coach, a coach first learns coaching. Coaching can be gained by attending coaching education at the University or through other educational channels such as sports coaches, training courses and so on. But the fact that many coaches who were former athletes are now coaches, upgrading the quality of a coach is very important. The trainer is required to compile a program from daily, monthly, annual and targets to be achieved in some time. Then the trainer must also be able to know the state of both psychic and physical athletes, the coach must have the quality of all technical, physical, and strategy matters.

In an effort to develop sports achievements, vital support elements are needed. One of these elements is a capable trainer. A competent trainer is a trainer who understands well the problems related to coaching, an athlete will have a far greater chance of success and achievement than individuals who do not use trainers who have no basis in coaching. Besides training in playing skills and techniques, what needs to be considered is physical exercise. Exercise can be done alone or coordinated in a management or training center. Physical conditions are a complete unity of components that cannot be separated, both their improvement and maintenance, meaning that in an effort to improve physical conditions, all components must be developed.

The trainer plays a major role in a coaching meaning that is according to Harsono (1988: 20) that the coach, inevitably, must know and deepen his areas of knowledge closely with his expertise. Most of the coaches are absent from knowledge in these sciences so that they will not produce athletes who have the maximum achievement.

Successful trainers according to Pate (1993: 24) master the art and science of communicating with sportsmen and their assistant coaches. They have the trust of their sports through active listening skills. They can foster a balance between taskoriented and sports-oriented and this balance always makes them win.

\section{METHOD}

The type of research in this research is qualitative and quantitative. The method is descriptive which is not intended to test a particular hypothesis, but only describes what it is about a variable, symptom or condition. The data collected in this study is data in the form of numbers, so this research is called quantitative descriptive research. In this study data collection techniques using questionnaires, which are supported by interview, observation, and documentation methods to obtain valid data.

\section{RESULT AND Discussion}

This research was conducted at Kei Shin Shin Kan KarateDo North Sumatra because it is a large university in North Sumatra. North Sumatra Province made the research area on the basis of: 1) having 8 pengcab namely Medan, Deli Serdang, Binjai, Tanah Karo, Central Tapanuli, Simalungun, Toba Samosir, and South Nias, 2) Owning 64 dojo and 1532 kohai. 3) Has \pm 80 trainers.

The subject of this research is Kei Shin Kan Karate-Do North Sumatra college which includes: coaches at Kei Shin Shin Kan Karate-Do North Sumatra. Respondents are a group of subjects who respond to

research questions. Respondents or research subjects are actively involved to actively participate in the discovery and formulation of problems, the process of research, data analysis to decision making. In this study, those who become respondents or research subjects are trainers. The subjects of the study were 18 Kei Shin Kan Pengcab trainers in Medan. 
The design of this study is qualitative research with an organizational management approach. Where the implementation of research based on four components of POAC, namely: Planning, Organizing, Actuacting and Controlling include:

\section{A. Planning}

It is one of the main functions in the management of sports achievement guidance and is essential for the implementation of management for work programs, to make a good plan.

\section{B. Organizing (Organizing)}

Organizing, however good the planning is arranged by the management, but if the implementation is not well organized, then the planning will not be able to achieve the specified target, therefore organizing is generally recognized as the second principal management function.

\section{Actuating}

Good planning and organizing is less meaningful if it is not followed by the implementation of responsible organizational work. For this reason, all available human resources must be optimized to achieve the vision, mission and work program of the management and trainer.

\section{Controlling (Control/Supervision)}

Controlling is not just controlling the implementation of the trainer program, managing facilities and infrastructure and other activities, but also supervising so that if necessary can make corrections.

Data analysis is the process of systematically finding and managing transcripts of interviews, field notes and other materials that have been collected to increase understanding of these materials and to enable reporting of what has been found to other parties.

Analysis includes activities working on data, arranging it, dividing it into one unit that can be managed, looking for patterns, finding what will be reported.

\section{References}

[1] Harsono. 1988. Aspek-aspek Psikologi dalam Coaching. Jakarta: CV. Tambak Kusuma Jakarta.

[2] Irenius Siriyei. 2013. Faktor Determinan Rendahnya Pencapaian Cakupan Standar Pelayanan Minimal Bidang Keseharan Di Puskesmas Mojo Kota Surabaya. Vol.1. No 3 Juli Agustus 2013.

[3] Rusli Lutan. 2000. Belajar Ketrampilan Motorik Pengantar Teori dan Metode. Jakarta: Depdikbud. Dirjendikti.

[4] RR.Pate, PF.Bodary dan Durstine, JL.(Terjemahan Oleh Kasijo,DW). 1993. Dasar dasar ilmiah kepelatihan. IKIP Semarang Press. 